UTILITY: Jurnal IImiah Pendidikan dan Ekonomi

Volume 3, No. 1, Februari 20xx: Page 15-28

ISSN 2549-1377 (Print) || ISSN 2549-1385 (Online)

Available online at http://journal.stkipnurulhuda.ac.id/index.php/utility

\title{
PENGARUH KONDISI SOSIAL EKONOMI ORANG TUA TERHADAP MOTIVASI SISWA MELANJUTKAN STUDI KE PERGURUAN TINGGI KELAS XII SMA MUHAMMADIYAH 2 KARANG TENGAH
}

\author{
Arianah $^{1}$, Dwi Susanti $^{2}$, Effendi $^{3}$ \\ Program Studi Pendidikan Ekonomi STKIP Nurul Huda Sukaraja \\ *E-mail: Dwisusanti@stkipnurulhuda.co.id
}

\begin{abstract}
Abstrak:Kondisi sosial ekonomi orang tua merupakan salah satu faktor eksternal timbulnya motivasi siswa untuk melanjutkan pendidikan. yang menjadi salah satu alasan siswa kelas XII SMA Muhammadiyah 2 Karang Tengah untuk tidak meneruskan ke Perguruan Tinggi adalah dikarenakan tekanan ekonomi. Selain itu, pekerjaan orang tua siswa $90 \%$ buruh dan petani. Pendidikan orang tua $65 \%$ lulusan SD dan SMP. Hal ini menjadi kendala bagi kelanjutan pendidikan untuk meneruskan ke Perguruan Tinggi. Tujuan dalam penelitian ini untuk mengetahui ada tidaknya pengaruh kondisi sosial ekonomi orang tua terhadap motivasi siswa dalam melanjutkan studi ke Perguruan Tinggi kelas XII SMA Muhammadiyah 2 Karang Tengah. Penelitian ini termasuk penelitian kuantitatif. Populasi dalam penelitian ini adalah kelas XII IPS SMA Muhammadiyah 2 Karang Tengah yang berjumlah 90 peserta didik. Sampel penelitian ini adalah kelas XII SMA Muhammadiyah 2 Karang Tengah yang berjumlah 39 peserta didik. Teknik pengumpulan data digunakan koesioner, sedangkan analisis data menggunakan regresi linier sederhana. Hasil akhir penelitian ini adalah Tidak terdapat pengaruh kondisi sosial ekonomi orang tua terhadap motivasi siswa dalam melanjutkan studi ke Perguruan Tinggi kelas XII SMA Muhammadiyah 2 Karang Tengah dengan harga thitung $=-0,912<-\mathrm{t} 0,05 ; 37=-1,687$ sehingga Ho diterima, sehingga Ha ditolak.
\end{abstract}

Kata Kunci: Kondisi Sosial Ekonomi, Motivasi

\section{PENDAHULUAN}

Tujuan akhir Anda adalah untuk membuat makalah yang sesuai dengan aturan baku jurnal Titian Ilmu. Untuk hal-hal yang tidak tercantum di panduan ini, silahkan mengacu pada informasi yang telah Anda dapatkan pada aturan penulisan ilmiah. Makalah dipersiapkan dalam bentuk softcopy dengan format ukuran kertas A4. Batas tepi: atas $=2,54 \mathrm{~cm}$, bawah $=2,54 \mathrm{~cm}$, sisi $=1,9 \mathrm{~cm}$. Lebar kolom pada A4 adalah 8,6 cm. Jarak antara dua kolom adalah 0,8 cm. Ukuran paragraf menjorok adalah $0,35 \mathrm{~cm}$. 
Pendidikan memiliki peranan yang sangat penting bagi kemajuan suatu bangsa, sehingga pendidikan harus terus menerus diperbaiki baik segi kualitas maupun kuantitasnya. Menurut UU Nomor 20 Pasal 17 Tahun 2003 Salah satu upaya pemerintah untuk meningkatkan mutu pendidikan di Indonesia adalah dengan mengadakan program wajib belajar 9 tahun pada jenjang pendidikan dasar, yaitu dari tingkat kelas 1 SD/MI hingga kelas 9 SMP/MTS. Pendidikan dasar diselenggarakan untuk mengembangkan sikap dan kemampuan serta memberikan pengetahuan dan keterampilan dasar yang diperlukan untuk hidup di dalam masyarakat serta mempersiapkan peserta didik yang memenuhi persyaratan untuk mengikuti pendidikan menengah.

Seiring dengan berjalannya waktu dan pembangunan dibidang pendidikan, peranan Perguruan Tinggi sangat penting untuk menyiapkan peserta didik menjadi anggota masyarakat yang memiliki kemampuan akademik profesional yang dapat menerapkan, mengembangkan dan atau menciptakan ilmu pengetahuan teknologi dan atau kesenian. Namun pada kenyataannya tidak semua lulusan SMA melanjutkan pendidikannya, hal ini disebabkan oleh beberapa faktor. Salah satu faktor yang diduga memberi andil didalam keberhasilan seorang siswa untukmelanjutkan pendidikan ke Perguruan Tinggi adalah kondisi sosial ekonomi orang tua.

Kondisi sosial ekonomi orang tua merupakan salah satu faktor eksternal timbulnya motivasi siswa untuk melanjutkan pendidikan, hal ini sesuai dengan pendapat Soemanto dalam Mamanggi (2013) yang mengatakan bahwa motivasi akan memberikan suatu dorongan atau semangat untuk bertingkah laku dalam melakukan kegiatan bagi seseorang untuk mencapai suatu tujuan yang dikehendaki, tanpa motivasi maka aktivitas hidup seseorang akan menurun.

Keluarga yang latar belakang sosial ekonominya baik dapat menunjang pendidikan anak-anaknya dan dapat memenuhi kebutuhan belajarnya. Sedangkan keluarga dengan tingkat sosial ekonomi yang kurang baik akan cenderung hanya mampu memenuhi kebutuhan hidupnya saja, yang menyebabkan kurangnya perhatian orang tua terhadap pendidikan anak. Pada umumnya kedudukan keluarga dalam masyarakat dipandang dari segi pendapatan, pekerjaan, dan pendidikan. Orang tua yang memiliki latar belakang sosial ekonomi yang tinggi dapat memenuhi kebutuhan pendidikan anaknya serta tidak akan mengalami kesulitan, bahkan orang tua berani 
mengeluarkan biaya khusus untuk pendidikan anaknya hingga ke Perguruan Tinggi. Hal ini berbeda dengan kondisi latar belakang sosial ekonomi orang tua yang rendah, mereka cenderung akan berusaha memenuhi kehidupan hidup sehari-hari daripada pendidikan anaknya.

Berdasarkan hasil wawancara salah satu guru SMA Muhammadiyah 2 Karang Tengah, yang menjadi salah satu alasan untuk tidak meneruskan ke Perguruan Tinggi adalah dikarenakan tekanan ekonomi. Dengan demikian motivasi siswa melanjutkan studi ke Perguruan Tinggi dapat dipengaruhi juga dari segi status sosial dan status ekonomi orang tua siswa. Selain itu, karena jenis pekerjaan orang tua siswa $90 \%$ adalah buruh dan petani. Pendidikan orangtua $65 \%$ adalah lulusan SD dan SMP. Kondisi tersebut akan menjadi kendala bagi kelanjutan pendidikan untuk meneruskan ke Perguruan Tinggi.

\section{KONDISI SOSIAL EKONOMI ORANG TUA}

Keadaan sosial ekonomi setiap orang berbeda-beda dan bertingkat, ada yang keadaan sosial ekonominya tinggi, sedang, dan rendah. Abdulsyani dalam Rahmawati (2007) berpendapat bahwa sosial ekonomi merupakan suatu keadaan yang menggambarkan penentuan kelas yang meliputi jenis aktivitas ekonomi, pendapatan, tingkat pendidikan, tipe rumah tinggal, jenis kegiatan rekreasi, jabatan dalam sebuah organisasi dan sebagainya. Iskandarwassid dan Sunendar dalam Haq (2011:130) menyatakan bahwa kemampuan sosial ekonomi orang tua merupakan sebuah latar belakang pencapaian posisi orang tua dalam masyarakat yang dapat memengaruhi keberhasilan belajar anak di sekolah. Dari pendapat tersebut dapat disimpulkan bahwa kondisi sosial ekonomi orang tua adalah keadaan yang menggambarkan kedudukan kondisi sosial ekonomi sebuah keluarga dalam lingkungan masyarakat dimana akan memengaruhi pula pendidikan yang diperoleh oleh anggotakeluarganya yakni anak. Dalam kehidupan bermasyarakat kondisi sosial ekonomi bisa dijadikan ukuran untuk menghargai seseorang. Sesuatu yang dihragai dalm masyarakat dapat berupa uang atau benda yang bernilai ekonomis, kekuasaan, ilmu pengetahuan, ataupun kesalehan beragama.

Menurut Soekanto yang dikutip oleh Herdiyanti (2015), hal - hal yang mempengaruhi status sosial ekonomi antara lain sebagai berikut: 
1. Ukuran kekayaan, semakin kaya seseorang, maka akan tinggi tingkat status seseorang dalam masyarakat.

2. Ukuran kekuasaan, semakin tinggi dan banyak wewenang seseorang dalam masyarakat, maka semakin tinggi tingkat status ekonomi seseorang tersebut.

3. Ukuran kehormatan, orang yang disegani di masyarakat akan ditempatkan lebih tinggi dari orang lain dalam masyarakat.

4. Ukuran ilmu pengetahuan, ilmu pengetahuan sebagai ukuran dipakai oleh masyarakat yang menghargai ilmu pengetahuan.

\section{MOTIVASI SISWA MELANJUTKAN STUDI KE PERGURUAN TINGGI}

Motivasi merupakan sarana bagi seseorang untuk menimbulkan dan menumbuhkan keinginan-keinginan agar dapat mencapai tujuan hidupnya. Menurut Sardiman (2016:73) motivasi adalah daya penggerak dari dalam dan di dalam subyek untuk melakukan aktivitas-aktivitas tertentu demi mencapai suatu tujuan. Sedangkan menurut Donald dalam Suryani (2005) menyatakan bahwa motivasi adalah suatu perubahan tenaga di dalam diri atau pribadi seseorang yang ditandai oleh dorongan efektif dan reaksi-reaksi dalam usaha mencapai tujuan.Dari definisi tersebut di atas, dapat diketahui bahwa motivasi merupakan suatu dorongan dari dalam diri manusia atau seseorang untuk melakukan sesuatu baik aktivitas atau sikap tertentu dalam bekerja, belajar maupun melakukan kegiatan lainnya guna mencapai tujuan yang diinginkan. Selain itu motivasi juga merupakan sarana bagi seseorang untuk menumbuhkan keinginan atau cita-cita untuk mencapai tujuan hidup yang diharapkan. Tujuan hidup dapat dicapai dengan pemenuhan kebutuhankebutuhan hidup baik berupa kebutuhan fisik maupun rohani.

Motivasi erat kaitannya dengan keinginan dalam diri siswa yang kuat dalam kegiatan pembelajaran. Siswa yang memiliki keinginan diri yang kuat dalam belajar akan menimbulkan beberapa fungsi positif yang dapat mempengaruhi motivasi belajar mereka. Fungsi motivasi menurut Sardiman (2016: 84) adalah sebagai berikut:

a. Mendorong manusia untuk berbuat, jadi sebagai penggerak atau motor yang melepaskan energi. Motivasi dalam hal ini 
merupakan motor penggerak dari setiap kegiatan yang akan dikerjakan.

b. Menentukan arah perbuatan, yakni kearah tujuan yang hendak dicapai. Dengan demikian motivasi dapat memberikan arah dan kegiatan yang harus dikerjakan sesuai dengan rumusan tujuannya.

c. Menyeleksi perbuatan, yakni menentukan perbuatan-perbuatan apa yang harus dikerjakan yang serasi untuk mencapai tujuan, dengan menyisihkan perbuatan-perbuatan yang tidak bermanfaat bagi tujuan tersebut. Misalnya saja seorang siswa yang akan menghadapi ujian dengan harapan dapat lulus, tentu akan melakukan kegiatan belajar dan tidak akan menghabiskan waktunya untuk bermain kartu, membaca komik, sebab tidak serasi dengan tujuan. Salah satu fungsi yang paling penting dari motivasi adalah untuk menggerakkan seseorang dalam setiap kegiatan pembelajaran yang akan dilakukan untuk mencapai tujuannya.

\section{METODE}

Dalam penelitian ini, metode yang digunakan adalah metode penelitian kuantitatif dengan jenis penelitian deskriptif. Desain penelitian ini menggunakan desain penelitian survey, menurut Sukmadinata(2013:29), penelitian survey digunakan untuk mengumpulkan data atau informasi tentang populasi yang besar dengan menggunakan sampel yang kecil. Populasi tersebut bisa berkenaan dengan orang, instasi, lembaga organisasi, unit-unit kemasyarakatan dan lain-lain.Populasi dalam penelitian ini adalah siswa kelas XII SMA Muhammadiyah 2 Karang Tengah IPS yang berjumlah 90 siswa. Sampel dalam penelitian ini berjumlah 39 siswa. Pengambilan sampel menggunakan simple random sampling yaitu dengan cara acak tanpa memperhatikan strata dari populasi itu. Alat pengumpulan data dalam penelitian ini adalah angket. 
Dalam penelitian ini penulis menggunakan angket tertutup untuk mengetahui data kondisi soial ekonomi orang tua siswa dan motivasi siswa melanjutkan studi ke PerguruanTinggi. Sedangkan pengukuran angket dalam penelitian ini menggunakan skala likert. Skala likert adalah skala yang dapat digunakan untuk mengukur sikap, pendapat, persepsi seseorang, untuk mengukur suatu objek atau fenomena sosial (Sugiyono, 2017:93-94). Adapun angket dalam penelitian iniberjumlah 20 pertanyaan untuk variable kondisi social ekonomi orang tua dan 20 pertanyaan untuk variable motivasi melanjutkan studi ke Perguruan Tinggi yang diberi skor5,4,3,2,1, dengan alternatif jawaban yaitu a,b,c,d,e.

\section{TEKNIK ANALISIS DATA}

Metode kuantitatif adalah metode analisis data yang menggunakan perhitungan ilmu statistik.

\section{Metode Analisis Deskriptif Persentase}

Analisis ini digunakan untuk mengetahui seberapa besar pengaruh variabel kondisi social ekonomi orang tua berpengaruh terhadap motivasi siswa melanjutkan studi ke Perguruan Tinggi. Statistik deskriptif adalah statistik yang digunakan untuk menganalisis dengan cara mendeskripsikan atau menggambarkan data yang telah terkumpul sebagaimana adanya tanpa bermaksud membuat kesimpulan yang berlaku untuk umum atau generalisasi (Sugiyono, 2013:207-208). Rumus yang digunakan adalah sebagai berikut :

$$
\mathrm{DP}(\%)=\frac{n}{N} \times 100 \%
$$

Keterangan:

DP atau \% : Deskriptif persentase

$\mathrm{n}$ : Nilai yang diperoleh

$\mathrm{N}$ : Jumlah seluruh nilai

1) Analisis Regresi Sederhana

Dalam penelitian ini penulis menggunakan teknik analisis data regresi linier sederhana. Sebelum pengujian hipotesis perlu dilakukan perhitungan rata-rata, standar deviasi dan kategori tinggi sedang rendah. Persamaan umum regresi linier sederhana di rumuskan sebagai berikut:

$$
\mathrm{Y}=\mathrm{a}+\mathrm{bX}
$$

Sumber : Sugiyono (2017: 188) 


$$
\begin{aligned}
& a=\frac{\sum Y-B \sum X}{n} \\
& b=\frac{n \sum X Y-\left(\sum X\right)\left(\sum Y\right)}{n \sum X^{2}-\left(\sum X\right)^{2}}
\end{aligned}
$$

Keterangan:

$a=$ intersep

$b=$ koefisien regresi

$n=$ sampel penelitian

$\mathrm{X}=$ variabel bebas

$\mathrm{Y}=$ variabel terikat

$\mathrm{X}=$ rata-rata variabel independen

1. Rata-rata

Rata-rata hitung (mean) dapat dirumuskan sebagai berikut:

$$
\begin{aligned}
& x=\frac{\sum X}{N} \quad \text { Keterangan: } \\
& x=\text { mean (rata-rata) } \\
& \sum X=\text { jumlah variabel } \mathrm{x} \\
& N=\text { jumlah responden } / \text { siswa }
\end{aligned}
$$

2. Standar Deviasi

$$
\begin{aligned}
& s^{2}=\sqrt{\frac{n \cdot\left(\sum x^{2}\right)-\left(\sum x\right)^{2}}{n(n-1)}} \\
& S^{2}=\text { Keterangan: } \\
& \sum X=\text { jumlan deviasi } \\
& n:=\text { banyaknyabel } \mathrm{x}
\end{aligned}
$$

3. Uji Prasyarat Hipotesis

Untuk melakukan pengujian hipotesis syarat yang harus dipenuhi dalam menggunakan statistik parametris adalah data tersebut harus memenuhi syarat normalitas. Uji normalitas dimaksudkan untuk mengetahui apakah sampel berasal dari populasi yang terdistribusi normal atau tidak. Uji normalitas dalam penelitian ini menggunakan rumus Zkurtosis dan Zskewnessdengan rumus dan ketentuan sebagai berikut:

$$
\begin{aligned}
& Z_{\text {Kurtosis }}=\frac{\text { Kurtosis }}{\sqrt{24 / n}} \\
& Z_{\text {Skewness }}=\frac{\text { Skewness }}{\sqrt{6 / n}}
\end{aligned}
$$


Dengan ketentuan untuk $\alpha=0,05$ jika $-1,96<\mathrm{Z}$ kurtosis $<1,96$ berarti data memiliki distribusi normal dan jika $-1,96<Z$ skewness $<1,96$ berarti data memiliki distribusi normal.

4) Uji Hipotesis

Dalam penelitian ini, pengujian hipotesis menggunakan uji t dapat dilakukan dengan menggunakan rumus sebagai berikut:

$$
\begin{aligned}
& t=\frac{r \sqrt{n-2}}{\sqrt{1-r^{2}}} \quad \text { (Sugiyono, 2017: 184) } \\
& \text { Keterangan: } \\
& t=\text { nilai t hitung } \\
& r=\text { besarnya koefisien } \\
& n=\text { jumlah sampel }
\end{aligned}
$$

\section{HASIL DAN PEMBAHASAN}

\section{Hasil}

Kondisi sosial ekonomi orang tua merupakan keadaan yang menggambarkan kedudukan kondisi sosial ekonomi sebuah keluarga dalam lingkungan masyarakat. Berdasarkan hasil observasi peneliti, kondisi social ekonomi orang tua tidak mempunyai pengaruh terhadap motivasi siswa melanjutkan studi ke Perguruan Tinggi.Seorang siswa yang mempunyai prestasi tetapi tidak didukung oleh kondisi social ekonomi orang tua yang baik malah lebih termotivasi giat belajar untuk memperoleh beasiswa guna melanjutkan ke perguruant inggi.Hal ini sesuai dengan pendapat Asih dalam Pujiati(2009) yang meyatakan bahwa Semakin baik prestasi yang diperoleh seseorang siswa, maka semakin tinggi juga motivasi siswa untuk melanjutkan pendidikan ke perguruan tinggi walau bagaimanapun keadaan orang tua, akan berusaha semaksimal mungkin untuk dapat menyekolahkan anaknya ke jenjang pendidikan pendidikan yang lebih tinggi. Berdasarkan pendapat tersebut dapat diketahui bahwa walaupun kondisi sosial ekonomi orang tua kurang baik, tidak mempengaruhi motivasi siswa untuk melanjutkan ke perguruan tinggi. Bahkan seorang siswa yang orang tuanya berpenghasilan kurang tinggi malah lebih termotivasi giat belajar untuk dapat memperoleh beasiswa guna melanjutkan ke Perguruan Tinggi. 
PENGARUH KONDISI SOSIAL EKONOMI ORANG TUA TERHADAP MOTIVASI

SISWA MELANJUTKAN STUDI KE PERGURUAN

TINGGI KELAS XII SMA MUHAMMADIYAH 2

KARANG TENGAH

\section{Pembahasan}

Penelitian ini menggunakan analisis deskriptif persentase dengan hasil sebagai berikut :

Tabel 1Persentase Hasil Angket Kondisi Sosial Ekonomi Orang Tua

\begin{tabular}{|c|c|c|c|}
\hline $\begin{array}{c}\text { Kondisi Sosial Ekonomi Orang } \\
\text { Tua }\end{array}$ & Skor & Frekuensi & Persentase \\
\hline Tinggi & $>68,86$ & 6 & $15,38 \%$ \\
Sedang & $50,42-68,86$ & 27 & $69,23 \%$ \\
Rendah & $<50,42$ & 6 & $15,38 \%$ \\
\hline \multicolumn{2}{|c|}{ Jumlah } & $\mathbf{3 9}$ & $\mathbf{1 0 0} \%$ \\
\hline
\end{tabular}

Tabel 2 Persentase Hasil Angket Motivasi Melanjutkan Studi KePerguruan Tinggi

\begin{tabular}{|c|c|c|c|}
\hline Motivasi & Skor & Frekuensi & Persentase \\
\hline Tinggi & $>79,85$ & 8 & $20,51 \%$ \\
\hline Sedang & $63,43-79,85$ & 25 & $64,10 \%$ \\
\hline Rendah & $<63,43$ & 6 & $15,39 \%$ \\
\hline \multicolumn{2}{|c|}{ Jumlah } & 39 & $100 \%$ \\
\hline
\end{tabular}

Dari tabel 1menunjukkan bahwa kondisi sosial ekonomi orang tua kelas

XII SMA Muhammadiyah 2 Karang Tengah adalah sedang. Hal tersebut dibuktikan dari perolehan skor hasil angket yang menunjukkan bahwa dari 39 peserta didik terdapat 6 siswa atau 15,38 \% menjawab kondisi sosial ekonomi orang tua dalam kategori tinggi, sedangkan 27 siswa atau 69,23\% menjawab kondisi sosial ekonomi orang tua dalam kategori sedang, sedangkan 6 siswa atau 15,38 \% menjawab kondisi sosial ekonomi orang tua dalam kategori rendah.

Sedangkan dari tabel 2 menunjukkan bahwa motivasi melanjutkan studi ke Perguruan Tinggi kelas XII SMA Muhammadiyah 2 Karang Tengah adalah sedang. Hal tersebut dibuktikan dari perolehan skor hasil angket yang menunjukkan bahwa dari 39 peserta didik terdapat 8 siswa atau 20,51\% menjawab motivasi siswa dalam melanjutkan studi ke Perguruan Tinggidalam kategori tinggi, sedangkan 25 siswa atau 64,10 \% menjawab motivasi siswa 
dalam melanjutkan studi ke Perguruan Tinggidalam kategori sedang, sedangkan 6 siswa atau 15,39\%.

Hasil perhitungan peneliti diperoleh persamaan analisis regresi sederhana yaitu:

$$
\begin{gathered}
: \hat{Y}=a+b X \\
Y=79,51-0,13 X .
\end{gathered}
$$

Dengan hasil perhitungan menggunakan product moment maka diperoleh korelasi sebesar $-0,148$ hal ini menunjukkan hubungan atau korelasi yang negatif dan lemah antara kondisi sosial ekonomi orang tua dengan motivasi siswa melanjutkan studi ke Perguruan Tinggi.

\section{Uji Hipotesis ( Uji T)}

Dalam penelitian ini dirumuskan dua hipotesis nol (Ho) dan Hipotesis alternatif (Ha) yang akan dibuktikan berdasarkan hasil perhitungan dan pengolahan data secara kuantitatif dengan kriteria sebagai berikut: 1) Jika hasil perhitungan $\mathrm{T}$ hitung lebih besar dari nilai $\mathrm{T}$ tabel dengan derajat kebebasan $\mathrm{n}$ 2 maka hasil penelitian signifikan dengan kata lain hipotesis alternatif (Ha) diterima dan Hipotesis nol (No) ditolak. 2) Jika hasil perhitungan $\mathrm{T}$ hitung lebih kecil dari nilai $\mathrm{T}$ tabel pada dengan derajat kebebasan $\mathrm{n}-2$ maka hasil penelitian tidak signifikan dengan kata lain Hipotesis alternatif (Ha) ditolak dan Hipotesis nol (Nol) diterima.Hasil perhitungan uji hipotesis diperoleh sebesart $_{\text {hitung }}=-0,912<-\mathrm{t}_{0,05 ; 37}=-1,687$ maka $\mathrm{H}_{0}$ diterima yang artinya tidak ada korelasi dan pengaruh yang signifikan antara kondisi sosial ekonomi orang tua dengan motivasi melanjutkan studi ke Perguruan Tinggi.

\section{SIMPULAN}

Berdasarkan data hasil penelitian diperoleh kesimpulan bahwa tidak ada pengaruh kondisi sosial ekonomi orang tua terhadap motivasi siswa melanjutkan studi ke Perguruan Tinggi kelas XII SMA Muhammadiyah 2 Karang Tengah. Hal ini diketahui dari hasil teknik analisis data sebagai berikut:

1. Kondisi sosial ekonomi orang tua SMA Muhammadiyah 2 Karang Tengah adalah sedang karna dari perhitungan persentase deskriptif dari 39 peserta 
didik terdapat 6 siswa atau 15,38 \% menjawab kondisi sosial ekonomi orang tuadalam kategori tinggi, sedangkan 27 siswa atau 69,23\% menjawab kondisi sosial ekonomi orang tuadalam kategori sedang, sedangkan 6siswa atau 15,38 \% menjawab kondisi sosial ekonomi orang tua dalam kategori rendah dengan nilai rata-rata hasil angket 59, 64 dan setandar deviasi 9,22.

2. Motivasi siswa melanjutkan studi ke Perguruan Tinggi SMA Muhammadiyah 2 Karang Tengah adalah sedang karna dari perhitungan persentase deskriptip dari 39 peserta didik terdapat 8 siswa atau 20,51\% menjawab motivasi siswa melanjutkan studi ke Perguruan Tinggi dalam kategori tinggi, sedangkan 25 siswa atau 64,10 \% menjawab motivasi siswa melanjutkan studi ke Perguruan Tinggi dalam kategori sedang, sedangkan 6siswa atau 15,39 \% menjawab motivasi siswa melanjutkan studi ke Perguruan Tinggi dalam kategori rendah dengan nilai rata-rata hasil angket 71,364 dan setandar deviasi 8,21.

3. Tidak ada pengaruh yang signifikan antara kondisi sosial ekonomi orang tua dengan motivasi siswa melanjutkan studi ke Perguruan Tinggi kelas XII SMA Muhammadiyah 2 Karang Tengah. Hal ini terbukti dengan hasil perhitungan teknik analisis data bahwat ${ }_{\text {hitung }}=-0,912<-\mathrm{t}_{0,05 ; 37}=-1,687$ yang berarti $\mathrm{H}_{0}$ diterima.

\section{Saran}

Adapun saran yang dapat diberikan melalui hasil penelitian ini adalah sebagai berikut:

1. Setelah melakukan penelitian di SMA Muhammadiyah 2 Karang Tengah, penulis menemukan bahwa banyak siswa yang mempunyai motivasi tinggi untuk melanjutkan studi ke perguruan tinggi, tetapi tidak di dukung oleh kondisi sosial ekonomi yang baik. Oleh karena itu, bagi orang tua siswa agar selalu memberikan dorongan semangat maupun materi kepada siswa. Sehingga dapat mendorong siswa untuk menumbuhkan semangat belajar, untuk mempersiapkan masa depan yang lebih baik dengan memberikan bekal pendidikan yang baik. Karena dengan bantuan dorongan semangat orang tua, bagi anak yang status sosial ekonominya kurang mampu akan lebih bersemangat untuk melanjutkan studi ke Perguruan Tinggi.

2. Bagi lembaga pendidikan SMA Muhammadiyah 2 Karang Tengah, dengan adanya fenomena tersebut diatas, agar senantiasa membantu memberikan dorongan dan semangat dan motivasi belajar kepada siswa serta membantu siswa dalam meningkatkan prestasi belajar siswa, sehingga dapat merangsang siswa untuk menumbuhkan motivasi melanjutkan studi 
Perguruan Tinggi. Karena hal ini juga akan membantu memberikan bekal pendidikan untuk masa depan siswa.

3. Bagi peneliti yang lain, agar menggunakan variabel-variabel yang lain selain di atas, hal ini untuk menambah wacana dalam dunia pendidikan yang berkaitan dengan motivasi sisa melanjutkan studi ke Perguruan Tinggi. Masih banyak faktor lain yang mempengaruhi motivasi siswa dalam melanjutkan studi ke Perguruan Tinggi.

\section{UCAPAN TERIMAKASIH}

Ucapan terimakasih ditujukan kepada SMA Muhammadiyah 02 Karang Tengah tempat dilakukannya penelitian dan juga STKIP Nuurul Huda Sukaraja tempat peneliti belajar dan mencari lmu.

\section{REFERENSI}

Haq, M. (2015). Pengaruh Prestasi Belajar, Kondisi Sosial Ekonomi Orang Tua, dan Self Efficacy Terhadap Minat Melanjutkan Studi Ke Perguruan Tinggi Pada Siswa Kelas XI IPS MAN 2 Semarang Tahun Ajaran 2014/2015. Skripsi. Semarang : Universitas Negeri Semarang.(online) tersedia di (http:Iip.unnes.ac.id/2230/5577.pdf. Diakses 25 desember $\underline{2017) .}$

Herdiyanti, R . (2016). Pengaruh Motivasi Belajar dan Status Sosial Ekonomi Orang Tua Terhadap Minat Melanjutkan Studi Ke Perguruan Tinggi Siswa Kelas XII IPS Semester Genap SMA Perintis 2 Bandar Lampung Tahun Pelajaran 2015/ 2016. Skripsi. Bandar Lampung : Universitas Lampung.

Mamanggi, K. (2013). Pengaruh Latar Belakang Sosial Ekonomi Orang Tua Terhadap Motivasi Siswa Melanjutkan Pendidikan Ke Perguruan Tinggi Siswa Kelas XII SMA Negeri 4 Jember Tahun Ajaran 2013/2014.Jurnal Terbitan Halaman 1-6.Jember: Universitas Jember.

Nasirotun, S. (2013). Pengaruh Kondisi Sosial Ekonomi Dan Pendidikan Orang Tua Terhadap Motivasi Melanjutkan Pendidikan Ke Perguruan Tinggi Pada SiswaSMK Kartika Aqasa Bhakti Semarang ".Jurnal Terbitan Vol. 1 No. 2, Oktober 2013 Halaman15-24. Semarang :IKIP Veteran Semarang. 


\section{PENGARUH KONDISI SOSIAL EKONOMI ORANG TUA TERHADAP MOTIVASI \\ SISWA MELANJUTKAN STUDI KE PERGURUAN TINGGI KELAS XII SMA MUHAMMADIYAH 2 \\ KARANG TENGAH}

Pujiati.(2009). Pengaruh Kondisi Sosial Dan Ekonomi Orang Tua Terhadap Motivasi Melanjutkan Studi Ke Perguruan Tinggi. Skripsi. Semarang : Universitas Negeri Semarang. (online) tersedia di (http:Iip.unnes.ac.id/2230/5577.pdf. Diakses 25 desember 2017 ).

Rahmawati, Y. Pengaruh Kondisi Ekonomi Orang Tua, Lingkungan Sekolah, Dan Prestasi Belajar Terhadap Minat Melanjutkan Pendidikan Tinggi Pada Siswa Kelas XII Akuntansi SMK Negeri 10 Surabaya ".Jurnal Terbitan Halaman 1-9. Surabaya: Universitas Negeri Surabaya.

Salmah. (2013). Pengaruh Status Sosial Ekonomi Keluarga Terhadap Motivasi Melanjutkan Ke Perguruan Tinggi Di MAS Pontianak" . Jurnal Terbitan Hal 1-13.Pontianak : Universitas Tanjungpura.

Sardiman. ( 2016). Interaksi dan Motivasi Belajar Mengajar. Jakarta: Raja Grafindo

Suryani, N. (2005). Pengaruh Kondisi Sosial Dan Ekonomi Orang Tua Terhadap Motivasi Melanjutkan Pendidikan Ke Perguruan Tinggi Di Kelas XI SMA PGRI 1 Kebumen .Jurnal terbitan halaman 189-205. Semarang: Universitas Negeri Semarang.

Sugiyono. (2012). Metode Penelitian Kuantitatif Kualitatif Dan $R \& D$. Bandung : Alfabeta

Sugiyono. (2017). Statistika Untuk Penelitian. Bandung : Alfabeta

Sukmadinata, N. (2013). Metode Penelitian Pendidikan. Bandung : Rosda

Undang-Undang RI No. 20 Tahun 2003. Tentang Sistem Pendidikan Nasional. 2003. Jakarta: Sinar Grafika.

Wulandari, F. (2012). Minat Siswa Melanjutkan Studi Ke Perguruan Tinggi Ditinjau Dari Status Sosial Ekonomi Orang Tua Dan Prestasi Belajar Pada Siswa Kelas XII SMA Negeri 1 Girimarto Tahun Ajaran 2012/2013 .Jurnal terbitan halaman 1-10.Surakarta: Universitas Muhammadiyah Surakarta. 